\author{
Michae Ba£dowski
}

\title{
Controversies Concerning the Interpretation of State Resources as a Prerequisite of State Aid: an Illustration Using the Example of Polish Green Certificates and the Auction System
}

\section{Introduction}

\section{The europeanisation of law $v$. national sovereignty}

Since the inception of the European Union, the Member States have been subject to the process of Europeanisation. In the legal field this meant changes in national laws as they were influenced by European law, or the influence of European law on the Member States' legal systems. ${ }^{1}$ On one hand this process has resulted in the harmonization of the Member States' legislation, but on the other it has decreased their autonomy and sovereignty. It also recurrently causes conflicts between the Member States and the European authorities. Cases concerning State aid are an excellent example of such conflict, where Member States constantly attempt to preserve as much control as possible over the supporting schemes. At the same time, the European Commission ${ }^{2}$ and the Court of Justice of the European Union ${ }^{3}$ tend to increase their supervisory power through a set of often controversial decisions and judgements. This article aims to provide a critical reflection on the CJEU and the EC's extensive interpretation of State resources as a prerequisite of State aid in financial schemes by using the example of Polish green certificates and auction systems that support producers of renewable energy sources. ${ }^{4}$

\section{Renewable energy sources in the European Union}

In 2007 the Member States of the EU set a target to cut greenhouse gas emissions and to increase energy production from RES, as well as to improve the energy efficiency by

1 A. Wróbel, Europeizacja polskiego prawa o posteppowaniu administracyjnym a autonomia proceduralna państw cztonkowskich Unii Europejskiej, in Europeizacja prawa administracyjnego, ed.

I. Rzucidło, Lublin 2011, p. 24.

2 Hereinafter: the EC.

3 Hereinafter: the CJEU.

4 Hereinafter: RES. 
$20 \%$ by $2020 .^{5}$ The targets were enacted in a legislation package called "2020 Climate and Energy Package" that includes, inter alia, Directive 2009/28/EC of the European Parliament and of the Council, ${ }^{6}$ which set the definition of RES, mandatory targets and the principles concerning the production and supporting of energy from RES. More recently Member States have developed further targets, which include, inter alia, an increase of up to $27 \%$ of energy production from RES by 2030.

However, the starting costs of energy production from RES are much higher compared to that from conventional sources and thus producers of RES energy would have difficulties in competing with conventional energy producers on a free market. Due to this market failure, the Member States are justified in creating support schemes that would enable RES producers to compete efficiently on the energy market. However, the support schemes cannot be granted arbitrarily since they have to meet the requirements set forth by EU law. Generally speaking, if the scheme fulfils the prerequisites of art. 107(1) of the Treaty of the Functioning of the European Union, ${ }^{7}$ it is considered to be State aid and thus the EC has to be notified, which then decides whether or not to raise objections regarding the scheme. In practice there are exceptions to these rules, which entail that the EC does not have to be notified if aid meets certain requirements. ${ }^{8}$

\section{The scope of the article}

During the last two decades a lot of controversies have arisen over numerous schemes concerning financial aid for RES. One of the main issues was whether those schemes fulfil the prerequisites of Article 107(1) TFEU, concerning State aid. The most problematic point was the interpretation of the prerequisite that aid is granted "through State resources." This article analyzes the CJEU jurisprudence concerning relevant State aid cases, as well as the EC decisions concerning RES financial aid schemes, to show the evolution of the definition of State resources and provide a critical analysis of the CJEU and the EC's approach. Relevant cases are analyzed by first describing the facts and explaining the reasoning behind each judgement or decision. Thereafter, a more general rule is synthesized and a critical application of the rule to supporting schemes is provided.

5 For some Member States the threshold was set at a lower level.

6 Directive 2009/28/EC of the European Parliament and of the Council of 23 April 2009 on the promotion of the use of energy from renewable sources and amending and subsequently repealing Directives 2001/77/EC and 2003/30/EC, OJ 2009 L140/16 (hereinafter: Renewable Energy Directive).

7 Treaty on the Functioning of the European Union (consolidated version), OJ 2008, C115/47 (hereinafter: TFEU).

8 Commission Regulation (EU) No 651/2014 of 17 June 2014 declaring certain categories of aid compatible with the internal market in application of Articles 107 and 108 of the Treaty, OJ 2014 L187/1. 
In order to show how difficult it can be to establish the existence of State resources in the supporting schemes, this article applies the CJEU and the EC reasoning to Polish green certificates and auction schemes for the four following reasons. Firstly, the EC has recently given a decision on the Polish green certificates scheme, which means it is the most recent ruling concerning these schemes. ${ }^{9}$ Secondly, the Polish authorities have already notified the EC of the auction system and this article provides predictions concerning the future decision. Thirdly, these schemes are considered as borderline cases, where it is not clear if they constitute State aid. ${ }^{10}$ Finally, there are numerous publications analyzing the Polish green certificates and auction schemes' compatibility with State Aid provisions. The authors of the publications have come to contradictory conclusions and justifications as to the existence of State aid in those schemes. This article therefore summarizes those opinions and provides a critical reflection on the authors' reasoning.

The article does not analyze whether other prerequisites of State aid are fulfilled, since their fulfilment is clear and in general does not raise any controversies. Furthermore, analysis of whether the green certificates and auction schemes comply with art. 107(3) TFEU ${ }^{11}$ is beyond the scope of this article.

\section{Polish RES supporting schemes}

\section{Legal framework}

From 2005, the green certificates scheme was regulated by the Energy Law Act of $1997 .{ }^{12}$ However, in 2011 the Polish Parliament started working on a new act that would redefine existing support schemes, introduce new ones, and collect all the regulation concerning RES into one, complex act. In 2015, the Polish Parliament passed the Renewable Energy Sources Act of $2015^{13}$ that introduced a new auction system scheme. There were numerous reasons for a gradual transition from using green certificates towards the auction system. The green certificates system supported mechanisms that could produce energy from RES at the lowest cost possible, rather than a more desired one, which could also

9 Case SA.37345 (2015/N), Polish certificates of origin.

10 W. Kucharski, Czy systemy wsparcia dla energii z odnawialnych zródet przewidziane w projekcie ustawy o OZE (druk sejmowy nr 2604) można uznać za pomoc publicznq?, Lublin 2015, p. 7, http://sjlegal.eu/wp-content/uploads/2015/04/Ustawa-o-oze-2015-om\%C3\%B3wienie-W. Kucharski-Lublin-2015-r.pdf 21.10.2016].

11 The compatibility of those schemes with the Article 107(3) TFEU is well presented in the article by Z.Z. Romanowska, Can support systems regarding renerwable energy (Parliamentary paper no. 2604) be considered as state aid?, "Przegląd Prawa Ochrony Środowiska” 2015, no. 2.

12 Dz.U. 2006 no. 89 item 625.

13 Dz.U. 2015 item 478 (hereinafter: Renewable Energy Sources Act). 
produce clean energy but for a higher price. ${ }^{14}$ Another issue was the increasing oversupply of the green certificates on the market, which had a negative impact on their prices.

\section{Green certificates}

The Polish green certificates system is based on certificates of origin. Producers of energy from RES obtain green certificates for the energy that they have produced from the President of the Polish Energy Regulatory Office, ${ }^{15}$ and the more energy they produce the more green certificates they obtain. Green certificates can then be sold on the Polish Power Exchange or through a private contract. At the same time, the major energy suppliers are obliged to purchase a certain number of green certificates every year. Instead of buying green certificates, energy suppliers may also pay a substitution fee collected and managed by a public body called The National Fund for Environmental Protection and Water Management. The substitution fee is used by the fund to finance environmental projects in Poland. The Polish green certificates scheme does not fix a minimum or maximum price for a green certificate.

\section{The auction system}

The new auction system, which the EC prefers over the green certificates scheme ${ }^{16}$ was introduced by the Renewable Energy Act that replaces the green certificates system for new RES producers. Producers that were operating before the creation of the auction system may still operate under the green certificates scheme until 2030. The Auction system introduces a complicated financial scheme to support RES producers, based on auctions that are organized by PURE. RES producers bid the amount of energy and the desired price. PURE sets the maximum price for the energy, which cannot be exceeded, as well as the amount of energy that will be put up for auction. The producer that bids the lowest price for selling the energy wins the auction. Different auctions are organized depending on the energy source and its power. RES producers that win the auction sell the energy for the price that they bid to the 'obliged sellers,'who are mainly energy suppliers. If the market price of the energy that is sold by obliged sellers is lower than the price paid to RES producers, then the sellers are entitled to compensation. The financial source of the compensation comes from the RES fee imposed on the end consumers. The government has created a special institution - OREO S.A. - which is responsible for the distribution of the RES fee from the end customers to the obliged sellers.

14 Z.Z. Romanowska, op. cit., p. 255.

15 Hereinafter: PURE.

16 Communication form the Commission, Guidelines on State aid for environmental protection and energy 2014-2020, OJ 2014 C 200/1. 


\section{The existence of state resources in green certificates and auction systems. A critical reflection on $\mathrm{CJEU}$ jurisprudence and $\mathrm{EC}$ decisions}

\section{State resources as a prerequisite of state aid}

According to Article 107(1) TFEU, any aid granted by a Member State or through State resources in any form whatsoever which distorts or threatens to distort competition by favoring certain undertakings or the production of certain goods shall, in so far as it affects trade between Member States, be incompatible with the internal market, unless otherwise provided in Treaties. Therefore, based on Article 107(1) TFEU and the CJEU jurisprudence, four prerequisites of State aid may be established. Those are: intervention by a State or through State resources, advantage on a selective basis, actual or potential distortion of competition, and an actual or potential effect of the on trade between Member States. Since it has already been established that green certificates and auction systems clearly meet all the prerequisites of State aid other than intervention through State resources, this article elaborates on the first prerequisite of State aid.

Neither hard law nor soft law provide a clear definition of State resources. In general, the prerequisite is fulfilled if there is a direct or indirect transfer of public resources. ${ }^{17}$ State resources can be interpreted as resources that belong to the State, a local government unit, or public or private companies controlled by the State. ${ }^{18}$ It is also important to note that the transfer of State resources cannot be understood only as the transfer of some kind of advantage, such as a financial grant. The prerequisite is also fulfilled if the State loses State resources in a way that constitutes a selective advantage for a beneficiary, such as a tax deduction or debt cancellation. ${ }^{19}$ One of the most important CJEU rulings that dealt with meeting the State resources prerequisite was the PreussenElektra case, which became a basis for further analysis of RES support schemes. The case concerned a financial scheme that was based on an obligation imposed by the German legislature on transmission and distribution system operators to purchase all energy from RES producers connected to their network for a fixed price higher than the market price. The CJEU ruled that this obligation imposed on private entities to purchase energy for such a fixed price involves neither direct nor indirect State resources. ${ }^{20}$ The Court stated that the fact that the obligation was imposed by the German legislature in a statute meant that State aid was not possible. The CJEU has also ruled out the argument that such an obligation would decrease the revenues gained by undertakings subject to provisions of

17 C-379/98 PreussenElektra AG vs. Schleswag AG (hereinafter: PreussenElektra, item 58).

18 C. Koenig, J. Kuhling, EC control of aid granted through State resources, "European State Aid Law Quarterly"2002, no. 1, p. 8.

19 C-518/13 Eventech Ltd. v. Parking Adjudicator (hereinafter: Eventech, item 33).

20 PreussenElektra, item 58. 
the statute, which would in turn decrease the State's income from taxes. The Court stated that such a consequence is an inherent feature of such a legislative provision and cannot be regarded as constituting a means of granting a particular advantage at the expense of the State. ${ }^{21}$ The undoubted importance of PreussenElektra is shown by the impact that it had on States in terms of creating support schemes that would shift the burden of financing RES to private parties and, at the same time, not fulfill the prerequisites of State Aid. However, the liberal approach taken in PreussenElektra was later narrowed down by both the CJEU and the EC expanding the definition of State resources.

The following criteria for establishing the existence of State resources, created by the CJEU and the EC, will be further analyzed, applied to green certificates or auction systems, and treated to critical reflection:

- the nature of a certificate of origin - the green certificates system,

- the creation of an alternative for payment to a private entity - the green certificates system,

- state control over private funds - green certificates and auction systems.

\section{The green certificate $-a$ thin line between state resources and a document}

The approach to the origin of green certificates was not consistent throughout the years and evolved mostly in the EC decisions. In the early decisions concerning green certificates schemes the EC ruled that certificates as such are not a State resource but rather an official documentation that states how much energy from RES a given entity had produced. This approach was taken by the EC, inter alia, in the cases concerning the UK green certificates system ${ }^{22}$ and the Swedish green certificates system. ${ }^{23}$ In its early approach, the EC compared green certificates to the scheme presented in the PresussenElektra case. The EC explained that an obligation is placed on private parties and the sole purpose of using green certificates is to show the quantity of energy produced from RES. Furthermore, the EC stated that no State resources are involved in such a scheme and there is no loss of revenue for the State. ${ }^{24}$ However, this liberal approach was drastically changed by more recent judgements and EC decisions. In a case concerning a Dutch scheme of tradable nitrogen oxides emission rights, ${ }^{25}$ the Court ruled that if the State provides documents free of charge that reflect the quantity of emission and which can later be sold, then this fulfills the prerequisite of State resources. Although the Dutch scheme in the NOx case did not support RES producers, the transmission documents used in the scheme are in principle identical to green certificates as such. Entities that

21 Ibidem, items 61-62.

22 Case N 504/2000, British Renewable Obligation I, OJ 2002, C 30/15.

23 Case N 789/2002, Swedish Green Certificates, OJ 2003, C 120/8.

24 Case N 504/2000, British Renewable Obligation I, OJ 2002, C 30/15, p. 12.

25 C-279/08 P Commission v. Netherlands ("Dutch NOx trading scheme") (hereinafter: NOx). 
produced more $N O x$ than the amount set by law were obliged to obtain a certain number of transmission documents or to decrease the NOx production, or both. The transmission documents were offered by companies with a level of $N O x$ production below the threshold set by the regulation on a special market. The reasoning of the Court was that the State creates an asset and a market on which this asset can be traded. By doing this it gives it a certain value that is transferred to the beneficiary of the aid free of charge. Further reasoning is that since those documents have a material value, they can be sold by the State to beneficiaries in a tender or an auction procedure. The fact that they are given something free of charge instead of using a tender or an auction procedure causes a loss to the State, and they therefore constitutes State resources. ${ }^{26}$ Identical reasoning was applied by the EC to the Romanian green certificates scheme. ${ }^{27}$ Therefore, it was predictable that in the most recent decision issued by the EC, the Polish green certificates system is also considered to be State Aid. ${ }^{28}$ It should be pointed out that some Polish authors claimed that Polish green certificates will not be considered as State aid, given the reasoning that stood behind the EC practice set in the UK and the Swedish decision. ${ }^{29}$ However, given the more recent EC decisions and CJEU judgements, which were already available at the time those articles were published, this argument cannot be accepted.

The outcome of the decision concerning Polish green certificates was as predictable as it was wrong. The approach taken by the CJEU in the NOx case, and further decisions that followed from that judgement, reveal there is a clear misunderstanding of the nature of a green certificate. Although the form of the certificate in fact differs from the approach taken by PreussenElektra, the outcome is essentially identical. In PreussenElektra the financial support was granted by private entities at a fixed price imposed by a German statute. In the green certificates scheme the aid is also paid by private entities, and it is imposed through national legislation, but the difference is that the price is not fixed, relying rather on the market price of a certificate. The difference therefore is the creation of an extra step in the scheme. In PreussenElektra the State grants the right to obtain financial support from a private entity, while in the green certificates scheme the State grants the right to obtain a certificate that details the amount of energy produced, which is converted to financial support from a private entity. Thus the source of the financial support in PreussenElektra does not come from a statute itself, but from resources taken from private entities and given to RES producers. In turn, in the green certificates

\section{NOx, item 111.}

27 Case SA.33134 (2011/N), Romanian Green Certificates, OJ 2011, C 244/2.

28 Case SA.37345 (2015/N), Polish certificates of origin, items 137-147.

29 D. Kobiałko, Czy systemy wsparcia dla energii z odnawialnych źródet przewidziane w projekcie ustawy o OZE (druk sejmowy nr 2604) można uznać za pomoc publiczna?., Warszawa 2015, p. 12, http://www.m.cire.pl/pliki/2/2877kobialkod3miejsce.pdf[access: 22.10.2016];Z.Z.Romanowska, op.cit., p 264. 
scheme the source of aid are resources taken from private entities and given to RES producers, and not a certificate as such. The argument provided by the CJEU and EC, namely that the certificates could be sold through an auction or a tender procedure and thus they would not constitute aid, is therefore erroneous since the green certificate is not a source of aid. It is also arguable whether introducing such a scheme would even be possible and effective and thus it may lead to the conclusion that, in order to escape from the State aid regime, States would have to choose less effective systems to support RES producers $^{30}$. Furthermore, the approach taken by the CJEU and EC can be stretched to such an extent that in every case concerning financial schemes the prerequisite of State resources will be met. If the CJEU states that the State loses its resources because it creates a certificate which has a value and gives it away for free, then one may argue that in PreussenElektra the State loses its resources as well because it could have issued such certificates, given them value, and then sold them through a tender procedure or an auction. It seems that this reasoning takes the CJEU approach to absurd conclusions. However, there are justified doubts whether the CJEU would give the same ruling on PreussenElektra today.

\section{The creation of a sanction system related with the green certificates scheme}

Throughout the European Union, Member States have created schemes based on certificates of origin that involved penalties for not acquiring a certain amount of certificates. The issue of paying a fine for not fulfilling the obligation to acquire green certificates was analyzed by the EC in the UK green certificates decision. The EC stated indirectly that a fine as such does not constitute a loss in State resources but that the problem lay in applying rules concerning State control over aid (this issue is discussed in section 3.4 of this article $)^{31}$. The penalty in the UK system was called a buy-out price and the resources granted through the fines were later redistributed to RES producers. An identical approach was taken by the EC in a case concerning Swedish certificates. ${ }^{32}$

However, once again the CJEU took a more restrictive approach to the existence of State resources in the NOx case, where it stated that transmission documents are an alternative to paying a fine and therefore they reduce the State's resources. ${ }^{33} \mathrm{It}$ is difficult to agree with the Court that a fine whose value exceeds the value of the certificate itself can be considered as an alternative. An obligation without a sanction is called a lex imperfecta in legal jargon, and in practice it is at least more difficult to enforce. Therefore, in order

30 W. Sauter, H. Vedder, State aid and selectivity in the context of emissions trading: comment on the NOx Case, "European Law Review" 2012, vol. 37, p. 334.

31 Case N 504/2000, British Renewable Obligation I, OJ 2002, C 30/15, p. 12.

32 Case N 789/2002, Swedish Green Certificates, OJ 2003, C 120/8, p. 5.

33 T.M. Rusche, EU Renewable Electricity Law and Policy -From National Targets to a Common Market, Cambridge 2015, p. 102. 
to escape the scope of article 107(1) TFEU, the Member States would have to create an ineffective scheme. The view that a green certificate is an alternative to a sanction cannot be accepted either, since the sanction could not exist without an obligation. A sanction for not fulfilling an obligation is an inevitable part of the scheme, just as a decrease in tax revenues was in the PreussenElektra case ${ }^{34}$. The necessity of providing a sanction in the green certificates schemes to ensure the effectiveness of the system has been confirmed by the CJEU in a recent case concerning the compatibility of the Swedish green certificates system with art. 34 TFEU $^{35}$.

In the articles concerning the Polish green certificates scheme, two opposite views concerning the existence of a fine may be established. One view shares the Court's reasoning expressed in the NOx case ${ }^{36}$, while others take an opposite approach ${ }^{37}$. Their opposite argument is based on the fact that the resources obtained through penalties are used to finance other purposes that do not concern RES producers and thus they are not part of a scheme. Although I agree that imposing a sanction for not fulfilling the obligation to obtain certificates does not involve State resources, I believe that the way that the money obtained through payment is spent is irrelevant. This particular sanction of paying a fine is inevitably correlated with the green certificates scheme and could not exist without it. Therefore, the way that the resources obtained from penalties are spent does not have an impact on the fact that such a sanction does not involve State resources, since it cannot be considered as an alternative to obtaining a certificate.

\section{State control over aid}

According to the well-established CJEU jurisprudence, if the resources - although funded from private funds - are controlled or distributed by an entity established by the State, then they are considered to be aid granted through State resources. ${ }^{38}$ This approach had been already taken by the CJEU before ruling on renewable energy support schemes. In Ladbroke Racing LTD, the Court ruled that even though the aid was not permanently held by the Treasury, the fact that it constantly remained under public control, and was therefore available to the competent national authorities, it was sufficient for it to be categorized as State resources. ${ }^{39}$ In the more recent Essent case, the CJEU developed and

34 PreussenElektra, item 62.

35 C-573/12 Ålands Vindkraft AB v. Energimyndigheten, item 116.

36 W. Szopiński, Czy systemy wsparcia dla energii z odnawialnych źródet przewidziane w projekcie ustawy o odnawialnych źródtach energii można uznać za pomoc publiczną?, 2015, pp. 10-11, http:// www.cire.p1/pliki/2/szopinskiw2miejsce.pdf [access: 15.03.2017].

37 D. Kobiałko, op. cit., p. 13; Z.Z Romanowska, op. cit., p. 259.

38 See C-83/98 P French Republic v. Ladbroke Racing Ltd and Commission (hereinafter: Ladbroke Racing Ltd); C-482/99 French Republic v. Commission; C-206/06 Essent Network Noord (hereinafter: Essent); C-262/12 Vent De Colère and others (hereinafter: Vent de Colere).

39 Ladbroke Racing Ltd, item 50. 
clarified criteria that establish whether a scheme in which the burden to finance aid lies with private entities constitutes State aid. ${ }^{40}$ The case concerned a financial scheme where so-called "stranded costs," which were borne by a public energy company SEM during an investment period, were recompensed through increased electricity prices transferred to the end customer. The aid was based on the Dutch Transitional Law, which imposed a charge on the end customers, while the transfer of money was supervised by the State. According to the Court, the State supervision over the money flow distinguished the Essent case from Pearle case, ${ }^{41}$ where the State could not exercise any control over the aid and the purpose of the aid was not established by law. ${ }^{42}$ Therefore, the following criteria may be established, based on the Essent judgement, that determine whether State resources are involved in a scheme: 1) the source and the purpose of the aid are defined by law, 2) the State exercises direct or indirect control over the aid, 3) appointment of a private or public body by the State to manage a State resource. ${ }^{43}$ This approach narrows down the criteria from the PreussenElektra judgement and is applied in the more recent Vent de Colere case, in which French law imposed an obligation to buy electricity produced from a wind power for a fixed price which was higher than the market price of that energy. ${ }^{44}$ The French scheme resembled the one presented in PreussenElektra; however, it granted the State the right to supervise the money flow of the aid, and imposed an obligation on the State to cover the negative difference between the costs borne by the RES producers and the amount of the aid collected from the private entities. ${ }^{45}$ Although in my opinion the State's supervision over the aid is in itself not sufficient to fulfil the prerequisite of State resources, the obligation imposed on the State to cover a negative difference clearly fulfils this prerequisite.

Therefore, financial schemes are considered aid imputable to the State and granted through its resources due to the sole fact that the State holds even indirect control over the distribution of those resources. This interpretation of State resources is relevant for both Polish green certificates and auction systems. In the green certificates system, the funds collected from penalties are controlled by a public fund, while in the auction system the redistribution of so-called RES charges is controlled by a public body.

In my opinion, the interpretation of article 107(1) TFEU that is presented by both the CJEU and EC stretches the definition to such an extent that if a State decides to transfer the burden to finance aid to private parties, in order not to fall under the scope of

40 F. R. Carmona, The Feed-in Tariffs Entanglement: A Comparative Study of the Analytical Approaches Followed by the EU and WTO Judiciary Bodies regarding Renewable Energy Subsidies, "Legal Issues of Economic Integration" 2016, vol. 43, no. 2, p. 223.

41 C-345/02 Pearle and Others.

42 Essent, item 72.

43 Essent, items 45, 66, 69-70, 72.

44 Vent de Colere, items 21-37.

45 Ibidem, item 26. 
Article 107(1) TFEU, it seems that it does not have any instruments to assure the proper distribution of those resources and therefore it cannot vouch for the effectiveness of the aid. The broad scope of State resources leaves the following dilemma. If the State grants aid financed by private resources, it either has to agree to fall under the scope of Article 107(1) TFEU, with all of the legal consequences that entails, or it has to waive the right to efficiently supervise the aid. Since Member States finance RES producers in order to comply with the obligations under Directive 2009/28/EC, the choice to resign from the right to supervise the aid could expose them to the unwanted risk of not fulfilling their obligations under the Directive. I do not find the argument that exercising public control over private funds renders them available to the public authorities convincing enough to qualify it as a fulfilment of the State resource prerequisite. An even wider approach was taken by the EC in the PreussenElektra judgment, where it stated that it is immaterial whether the aid is financed directly through the state resources or indirectly through private funds. According to the EC, such a distinction would make it possible to circumvent the State Aid rules and it would jeopardize the attainment of the objectives of the Treaty ${ }^{46}$. Therefore, according to the more economic approach presented by the EC, which focuses more on the effects of the scheme, rather than on the wording of Article 107(1), the scheme presented in PreussenElektra would be considered as State Aid. Although this approach cannot be accepted, as it directly contradicts Article 107(1) TFEU, those financial schemes can still be challenged as contradictory to Article 34 TFEU. Under this provision, all measures having an equivalent effect to quantitative restrictions on imports, including any national measure which is capable of hindering, directly or indirectly, actually or potentially, intra-Community trade are prohibited. ${ }^{47}$ For these reasons I find that both the CJEU and EC actions which broaden the scope of the State resources prerequisite to be wrong. Instead of bending the definition of State aid, which unnecessarily causes different aid schemes to fall under Article 107 TFEU, with all the consequences this entails, other measures can be successfully taken to prevent States from distorting competition. It needs to be pointed out that arguments for and against broadening the definition of State resources have consequences that reach much further than renewable energy schemes, and thus cannot be limited to a discussion between environmentalists and free-markets supporters. ${ }^{48}$ Such practices extend the EC and CJEU's control over the Member States in a way that does not have any reflection in any hard law, and it also compromises the efficacy of the financial schemes with an

46 R. Callaerts, State Aid for the Production of Electricity from Renewable Energy Resources, "European Energy and Environmental Law Review”2015, vol. 24, p. 21.

47 C-573/12, Alands Vindkraft AB v. Energimyndigheten; Joined cases C-204 to 208/12 Essent Belgium NV v. Vlaamse Reguleringsinstantie voor de Elektriciteits- en Gasmarkt.

48 T.M. Rusche, op. cit., p. 111. 
extensive control, which could be more proportionally assured by applying Article 34 TFEU instead of stretching the definition of State resources to the maximum. ${ }^{49}$

\section{Conclusions}

Tim Rusche very accurately described the PreussenElektra judgement as a "Pyrrhic victory." ${ }^{50}$ Indeed, although the judgement encouraged the creation of financial schemes that would not fall under the scope of Article 107(1) TFEU, soon the EC and CJEU abruptly deflated the Member States' optimism by gradually expanding the scope of the definition of aid granted through State resources. It is actually astonishing how far the jurisprudence went - from a very simple term to the very narrow conditions set by the Essent case concerning State control over the funds, or by proposing unrealistic tender conditions concerning tradable rights to emissions in the NOx case. However, given the Court's jurisprudence and the EC decisions, it is certain that both Polish green certificates and the auction system will be considered State aid, this does not preclude the necessity for expressing strong opposition to the practice of misrepresenting the definition of State resources. At the end of the day, this practice will not only affect RES support schemes but the whole State aid system, causing unnecessary bureaucracy and inefficiency instead of supporting and promoting more efficient solutions.

\section{Literature}

Callaerts R., State Aid for the Production of Electricity from Renewable Energy Resources, "European Energy and Environmental Law Review" 2015, vol. 24.

Carmona F. R., The Feed-in Tariffs Entanglement: A Comparative Study of the Analytical Approaches Followed by the EU and WTO Judiciary Bodies regarding Renewable Energy Subsidies, "Legal Issues of Economic Integration" 2016, vol. 43, no. 2.

Kobiałko D., Czy systemy wsparcia dla energii z odnawialnych źódet przewidziane w projekcie ustawyo OZE (druk sejmowy nr 2604) można uznać za pomoc publiczna?, Warszawa 2015, http://www.m.cire.pl/pliki/2/2877kobialkod3miejsce.pdf [access: 22.10.2016].

Koenig C., Kuhling J., EC control of aid granted through State resources, "European State Aid Law Quarterly"2002, no. 1.

Kucharski W., Czy systemy wsparcia dla energii z odnawialnych źródet przewidziane w projekcie ustawy o OZE (druk sejmowy nr 2604) można uznać za pomoc publiczna??, Lublin

49 More information concering the apllication of the Article 34 TFEU may be found in A. Steinbach, R. Bruückmann, Renerwable Energy and the Free Movement of Good, "Journal of Environmental Law" 2015, vol.27, pp.1-16.

50 Ibidem, p. 2. 
2015,http://sjlegal.eu/wp-content/uploads/2015/04/Ustawa-o-oze-2015-om\%C3\% B3wienie-W.Kucharski-Lublin-2015-r..pdf [21.10.2016].

Romanowska Z.Z., Can support systems regarding renewable energy (Parliamentary paper No. 2604) be considered as state aid?, "Przegląd Prawa Ochrony Środowiska" 2015, no. 2. Rusche T.M., EU Renewable Electricity Law and Policy - From National Targets to a Common Market, Cambridge 2015.

Sauter W., Vedder H., State aid and selectivity in the context of emissions trading: comment on the NOx Case, "European Law Review" 2012, vol. 37.

Steinbach A., Bruückmann R., Renewable Energy and the Free Movement of Good, "Journal of Environmental Law" 2015,vol. 27.

Szopiński W., Czy systemy wsparcia dla energii z odnawialnych źódet przewidziane w projekcie ustawy o odnawialnych źródtach energii można uznać za pomoc publiczna??, 2015, http://www.cire.pl/pliki/2/szopinskiw2miejsce.pdf [access: 15.03.2017].

Wróbel A., Europeizacja polskiego prawa o postępowaniu administracyjnym a autonomia proceduralna państw cztonkowskich Unii Europejskiej, in Europeizacja prawa administracyjnego, ed. I. Rzucidło, Lublin 2011.

Case C-206/06 Essent Network Noord [2008] ECR I-5497.

Case C-262/12 Vent De Colère and others [2013] ECR I-851.

Case C-279/08 P Commission v. Netherlands [2011] ECR I-0000.

Case C-345/02 Pearle and Others [2004] ECR I-7139.

Case C-379/98 PreussenElektra AG v. Schleswag AG [2001] ECR I-2159.

Case C-482/99 French Republic v. Commission [2002] I-04397.

Case C-518/13 Eventech Ltd. v. Parking Adjudicator [2015] ECLI: EU: C: 2015: 9.

Case C-573/12 Ålands Vindkraft AB v. Energimyndigheten [2014] ECLI:EU: C: 2014:2037.

Case N 504/2000 British Renewable Obligation I, OJ 2002, C 30/15.

Case N 789/2002 Swedish Green Certificates, OJ 2003, C 120/8.

Case C-83/98 P French Republic v. Ladbroke Racing Ltd and Commission [2000] I-03271.

Case SA.33134 (2011/N), Romanian Green Certificates, OJ 2011, C 244/2.

Case SA.37345 (2015/N), Polish certificates of origin.

Commission Regulation (EU) no. 651/2014 of 17 June 2014 declaring certain categories of aid compatible with the internal market in application of Articles 107 and 108 of the Treaty, OJ 2014 L187/1.

Communication form the Commission, Guidelines on State aid for environmental protection and energy 2014-2020, OJ 2014 C 200/1.

Directive 2009/28/EC of the European Parliament and of the Council of 23 April 2009 on the promotion of the use of energy from renewable sources and amending and subsequently repealing Directives 2001/77/EC and 2003/30/EC, OJ 2009 L140/16. 
282 | Adam Mickiewicz University Law Review

Joined cases C-204 to 208/12 Essent Belgium NV v. Vlaamse Reguleringsinstantie voor de Elektriciteits- en Gasmarkt [2014] EU: C: 2014: 2192.

Treaty on the Functioning of the European Union (consolidated version), OJ 2008, C115/47.

Ustawa z dnia 10 kwietnia 1997 r. Prawo energetyczne (Dz.U. 2006 no. 89 item 625).

Ustawa z dnia 20 lutego 2015 r. o odnawialnych źródłach energii (Dz.U. 2015 item 478).

\section{SUMMARY}

Controversies Concerning the Interpretation of State Resources as a Prerequisite of State Aid: an Illustration Using the Example of Polish Green Certificates and the Auction System

The process of Europeanisation in the legal field results in various conflicts between the Member States and European authorities. Cases concerning State aid are an example of such a conflict, where on one hand Member States want to preserve control over various supporting schemes and on the other the European Commission and the Court of Justice of the European Union through a set of judgements and decisions increase their supervisory power over the supporting schemes. The European jurisprudence tend to stretch the scope of State aid by expanding the definition of State resources, which is one of its prerequisites. Applying of such a broad definition of State resources to Polish green certificates scheme and the auction scheme shows negative results of this approach that not only decreases the efficiency of the Renewable Energy Sources supporting schemes but that has a negative reflection on the whole State aid system.

Keywords: State aid, State resources, green certificates, auction, renewable energy sources

Michaє Ba£dows кi, University of Warsaw, Faculty of Law and Administration, Krakowskie Przedmieście 26/28, 00-927 Warszawa, Republic of Poland e-mail: michal.baldowski@gmail.com. 